\title{
Functionalization of heterocyclic compounds using polyfunctional magnesium and zinc reagents
}

\author{
Paul Knochel", Matthias A. Schade, Sebastian Bernhardt, \\ Georg Manolikakes, Albrecht Metzger, Fabian M. Piller, \\ Christoph J. Rohbogner and Marc Mosrin
}

\author{
Review \\ Address: \\ Department Chemie, Ludwig-Maximilians-Universität München, \\ Butenandtstr. 5-13, 81377 München, Germany \\ Email: \\ Paul Knochel* - knoch@cup.uni-muenchen.de \\ * Corresponding author \\ Keywords: \\ cross-coupling; heterocycles; insertion; metalation; \\ organomagnesium; organozinc
}

Open Access

\author{
Beilstein J. Org. Chem. 2011, 7, 1261-1277. \\ doi:10.3762/bjoc.7.147 \\ Received: 29 April 2011 \\ Accepted: 21 July 2011 \\ Published: 13 September 2011 \\ This article is part of the Thematic Series "Directed aromatic \\ functionalization". \\ Guest Editor: V. Snieckus \\ (c) 2011 Knochel et al; licensee Beilstein-Institut. \\ License and terms: see end of document.
}

\begin{abstract} tions in the Supporting Information File 1 of this article.

\section{Introduction}

The functionalization of heterocyclic scaffolds is an important task in current pharmaceutical research. In this review article, we describe the approaches to this problem that use functionalized magnesium and zinc heterocyclic intermediates. Some typical experimental procedures are indicated in each case for the most important methods. New Pd-catalyzed cross-coupling procedures are also presented.
\end{abstract}

In this review we summarize the most important procedures for the preparation of functionalized organzinc and organomagnesium reagents. In addition, new methods for the preparation of polyfunctional aryl- and heteroaryl zinc- and magnesium compounds, as well as new Pd-catalyzed cross-coupling reactions, are reported herein. Experimental details are given for the most important reac-

\section{Review}

1 Preparation of heterocyclic zinc reagents Organozinc compounds [1-3] are important synthetic intermediates as they are compatible with a broad range of functional groups. The reactivity of a carbon-zinc bond is quite low, and therefore, reactions with organic electrophiles often require the use of transition metal catalysts. The preparation of aryl and heteroaryl zinc derivatives is conveniently achieved by three general procedures:

- the direct insertion of zinc dust to aryl or heteroaryl iodides or bromides;

- the direct insertion of magnesium in the presence of $\mathrm{Zn}$ (II) salts to aryl or heteroaryl halides;

- the metalation of aryl or heteroaryl derivatives with $\mathrm{TMP}_{2} \mathrm{Zn} \cdot 2 \mathrm{MgCl}_{2} \cdot 2 \mathrm{LiCl}$. 
These three methods, developed recently in our laboratories, provide access to numerous heterocyclic zinc reagents (Scheme 1).

(i)

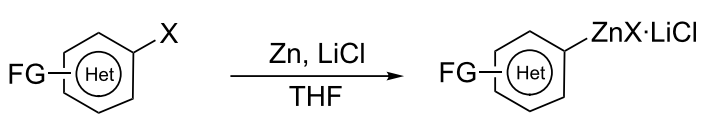

$$
\mathrm{X}=\mathrm{Br} \text {, I }
$$

(ii)

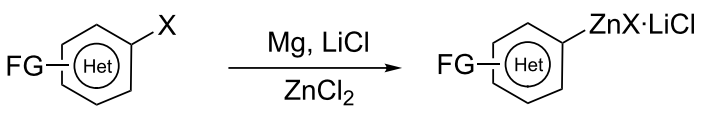

$\mathrm{X}=\mathrm{Cl}, \mathrm{Br}, \mathrm{I}$

(iii)

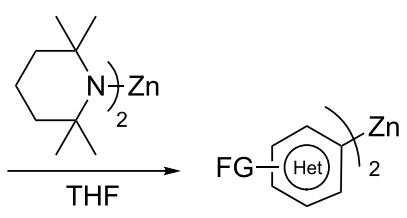

Scheme 1: Preparation of polyfunctional heteroarylzinc reagents.

\subsection{The direct insertion of zinc in the presence of $\mathrm{LiCl}$}

Although the direct insertion of zinc dust to alkyl iodides proceeds readily, the insertion to aryl iodides is very slow in THF and requires the use of polar solvents [4] or highly activated zinc [5]. Recently, we found that the presence of $\mathrm{LiCl}$ greatly facilitates the insertion of zinc to aryl iodides [6]. Thus, the insertion of zinc dust (activated with 1,2-dibromoethane and $\mathrm{Me}_{3} \mathrm{SiCl}$ ) to ethyl 4 -iodobenzoate (1) at $70{ }^{\circ} \mathrm{C}$ provides less than $5 \%$ of zinc reagent 2 after a reaction time of $24 \mathrm{~h}$. On the other hand, in the presence of one equivalent of $\mathrm{LiCl}$, the insertion of zinc is completed within $24 \mathrm{~h}$ at $25{ }^{\circ} \mathrm{C}$. After the addition of a catalytic amount of $\mathrm{CuCN} \cdot 2 \mathrm{LiCl}$ [7], the arylzinc intermediate is allylated with allyl bromide providing the ester 3 in $94 \%$ isolated yield (Scheme 2) [6].

This method can be extended to a broad variety of functionalized heterocyclic iodides such as the pyridines 4 and 7 . The corresponding zinc reagents $\mathbf{5}$ and $\mathbf{8}$ are obtained at $25{ }^{\circ} \mathrm{C}$ in quantitative yield. The allylation of pyridylzinc derivative $\mathbf{8}$ with allyl bromide provides pyridine 9 in $85 \%$ yield [6]. Interestingly, a diiodide, such as 2,5-diiodothiophene (10) reacts selectively with $\mathrm{Zn}$ and $\mathrm{LiCl}$ to provide the iodothienyl ketone 11 in $94 \%$ yield after benzoylation. Subsequent treatment of $\mathbf{1 1}$ with a second amount of $\mathrm{Zn}$ and $\mathrm{LiCl}$ (1.4 equiv) provides a new intermediate zinc reagent within $10 \mathrm{~min}$, which after allylation provides the 2,5-disubstituted thiophene 12 in $87 \%$ yield (Scheme 3) [6]. The insertion reaction proceeds best with aryl and heteroaryl iodides, however, the presence of electron-withdrawing substituents greatly accelerates the zinc insertion rate and electron-poor-heteroaryl bromides, such as the bromofuran 13, react smoothly with $\mathrm{Zn}$ and $\mathrm{LiCl}$ to furnish the furylzinc reagent 14 within $12 \mathrm{~h}$ at $25^{\circ} \mathrm{C}$, which after Pd-catalyzed crosscoupling (Negishi reaction) affords the 5-arylated furan $\mathbf{1 5}$ in $89 \%$ yield.

Interestingly, a high chemoselectivity is observed with several heterocyclic dihalides [8,9]. Thus, the tribromopyrimidine $\mathbf{1 6}$ provides only the 4-zincated pyrimidine $\mathbf{1 7}$. After allylation, the expected allylated pyrimidine $\mathbf{1 8}$ is obtained in $63 \%$ yield. Also, the dibromothiazole 19 allows insertion of zinc only into the most labile $\mathrm{C}-\mathrm{Br}$ bond (in position 2) leading to the zincated thiazole 20. After Negishi cross-coupling [10-12], the 2 -arylated thiazole $\mathbf{2 1}$ is obtained in $85 \%$ yield. Polar func-<smiles>CCOC(=O)c1ccc(I)cc1</smiles>

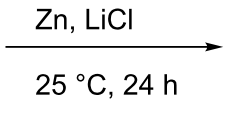<smiles>Oc1ccc(I)cn1</smiles>

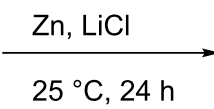
4

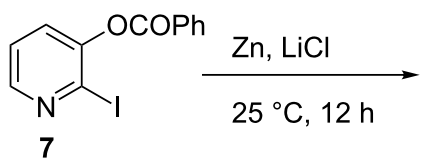<smiles>CCOC(=O)c1ccc([Ge]Cl)cc1</smiles><smiles>O=C(C=CCCl)OCl</smiles>

1) $\mathrm{CuCN} \cdot 2 \mathrm{LiCl}$

2) $\mathrm{MeCOCl}$

1) $\mathrm{CuCN} \cdot 2 \mathrm{LiCl}$<smiles>O=C(Oc1cccnc1[18O]c1ccccc1)c1ccccc1</smiles><smiles>C=CCc1ccc(C(=O)OCC)cc1</smiles>

3: $94 \%$<smiles>CCCCCOc1ccc(C(C)=O)cn1</smiles>
6: $83 \%$<smiles>C=CCc1ncccc1OC(=O)c1ccccc1</smiles> 


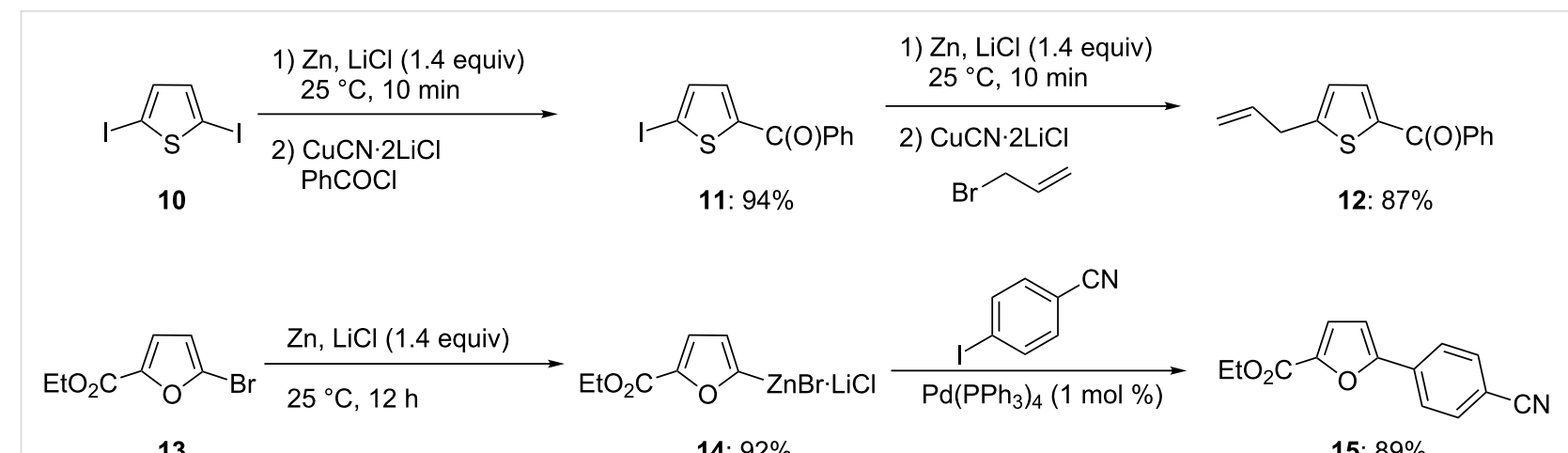

13

14: $92 \%$

15: $89 \%$

Scheme 3: Selective insertions of $\mathrm{Zn}$ in the presence of $\mathrm{LiCl}$.

tional groups, such as a tosyloxy-group are able to direct the zincation. Thus, the diiodoquinoline $\mathbf{2 2}$ is regioselectively zincated $\left(25^{\circ} \mathrm{C}, 12 \mathrm{~h}\right)$ to intermediate 23 leading to the polyfunctional quinoline $\mathbf{2 4}$ in $\mathbf{7 8 \%}$ yield after copper(I)-mediated acylation (Scheme 4 and Supporting Information File 1, Procedure 1) [8]. This regioselectivity is explained by the polar and electron-poor nature of the tosyloxy group, which leads to a strong electron-withdrawing effect and accelerates the insertion of zinc into the neighboring $\mathrm{C}-\mathrm{I}$ bond. The presence of $\mathrm{LiCl}$ amplifies this effect through coordination to the tosyloxy group and to the ortho-iodide, and therefore facilitates the cleavage of this carbon-iodide bond.

This method has been extended to the preparation of benzylic zinc reagents [13]. A remarkable chemoselectivity is observed and functional groups, such as an acetyl group, are perfectly compatible with such synthesis. Thus, the reaction of the benzylic chloride 25 with zinc dust (1.5 equiv) and $\mathrm{LiCl}$ ( 1.5 equiv) in THF at $25^{\circ} \mathrm{C}$ for $3.5 \mathrm{~h}$ provides the corresponding zinc reagent 26 in $68 \%$ yield. Its half-life at $25{ }^{\circ} \mathrm{C}$ is approximately two days. The copper(I)-mediated acylation of $\mathbf{2 6}$ provides the expected diketone $\mathbf{2 7}$ in $\mathbf{7 4 \%}$ yield (Scheme 5) $[13,14]$.

A broad range of functional groups are tolerated, and homocoupling products account for less than $5 \%$ of the total. These benzylic zinc reagents give access to biologically important phenylacetic acids. Thus, the treatment of the chloro-substituted benzylic zinc compound $\mathbf{2 8}$ with $\mathrm{ClCO}_{2} \mathrm{Et}$ in the presence of $\mathrm{Pd}\left(\mathrm{PPh}_{3}\right)_{4}(5 \mathrm{~mol} \%)$ furnishes the phenylacetic derivative 29<smiles>Brc1cc(Br)nc(Br)n1</smiles>

16

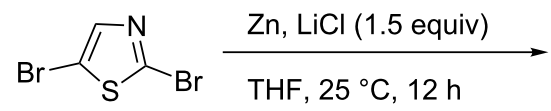

19

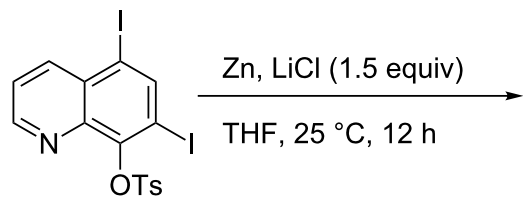

22<smiles>Brc1cc(Br)nc(Br)n1</smiles>

17: $91 \%$<smiles>C=C(CBr)COC(=O)Cc1cc(Br)nc(Br)n1</smiles>

18: $63 \%$<smiles>O=Cc1ccccc1-c1ncc(Br)s1</smiles>

21: $85 \%$ 
<smiles>CC(=O)c1cccc(CCl)c1</smiles>

$\mathrm{Zn}$ (1.5 equiv) $\underset{\mathrm{THF}, 25^{\circ} \mathrm{C}, 3.5 \mathrm{~h}}{\mathrm{LiCl}(1.5 \text { equiv })}$

25<smiles>O=CCc1ccccc1Cl</smiles>

29: $81 \%$

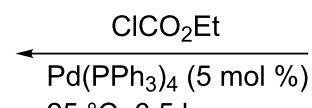

$25^{\circ} \mathrm{C}, 6.5 \mathrm{~h}$<smiles>CC(=O)c1cccc(Cc2ccccc2)c1</smiles>

26: $68 \%$

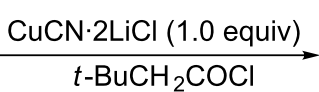

$-\mathrm{BuCH}_{2} \mathrm{COCl}$<smiles>CC(=O)c1cccc(CC(=O)CC(C)(C)C)c1</smiles>

27: $74 \%$<smiles>COc1ccc(CCl)cc1OC</smiles>

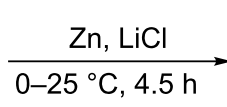
30<smiles>Clc1ccccc1C[14Cl]</smiles>

28

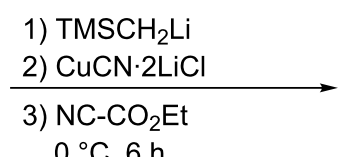

$0{ }^{\circ} \mathrm{C}, 6 \mathrm{~h}$

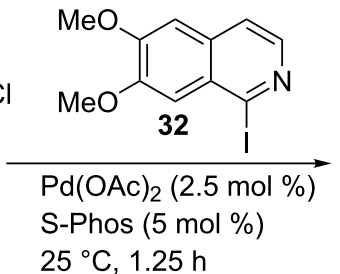

$25^{\circ} \mathrm{C}, 1.25 \mathrm{~h}$<smiles>CCOC(=O)Cc1ccccc1Cl</smiles>

29: $77 \%$<smiles>COc1ccc(Cc2nccc3cc(OC)c(OC)cc23)cc1OC</smiles>

33: papaverine; $68 \%$

Scheme 5: Preparation and reactions of benzylic zinc reagents

in $81 \%$ yield. Alternatively, a copper (I)-mediated reaction with $\mathrm{NC}-\mathrm{CO}_{2} \mathrm{Et}$ provides the same product in $77 \%$ yield when a dummy ligand is added (Scheme 5) [13]. Electron-rich benzylic chlorides, such as $\mathbf{3 0}$ are also readily converted to the desired zinc reagents 31 . The Pd-catalyzed cross-coupling of $\mathbf{3 1}$ with the iodoquinoline 32 and with S-Phos as ligand [15-17] provides the alkaloid papaverine (33) in $68 \%$ yield (Scheme 5) [13]. Ni-catalyzed cross-couplings can also be realized [14]. Thus, the reaction of the benzylic zinc reagent 34 , obtained by direct zinc insertion in the presence of $\mathrm{LiCl}$, with the chloropyridine 35 in the presence of $\mathrm{Ni}(\mathrm{acac})_{2}(0.5 \mathrm{~mol} \%)$ and $\mathrm{PPh}_{3}$ ( 2 mol \%) affords the polyfunctional pyridine 36 in $90 \%$ yield (Scheme 6 and Supporting Information File 1, Procedure 2) $[14,18,19]$.
1.2 The direct insertion of magnesium in the presence of $\mathrm{ZnCl}_{2}$ : A new preparation of unsaturated zinc reagents bearing sensitive functionalities

Although the LiCl-mediated zinc insertion represents a major preparative advance for the synthesis of polyfunctional zinc reagents, this method has an intrinsic limitation due to the use of zinc as a reducing agent. Zinc has only moderate reducing properties, therefore its insertion into organic halides only proceeds smoothly in the case of aryl iodides and electron-poor substituted aryl bromides. The use of highly reactive zinc (Rieke-zinc) [20,21] solves the problem only partially. It is expensive and most aryl or heteroaryl chlorides do not react. Therefore, we used a stronger reducing reagent, magnesium. Magnesium turnings readily insert into a variety of aryl chlo-

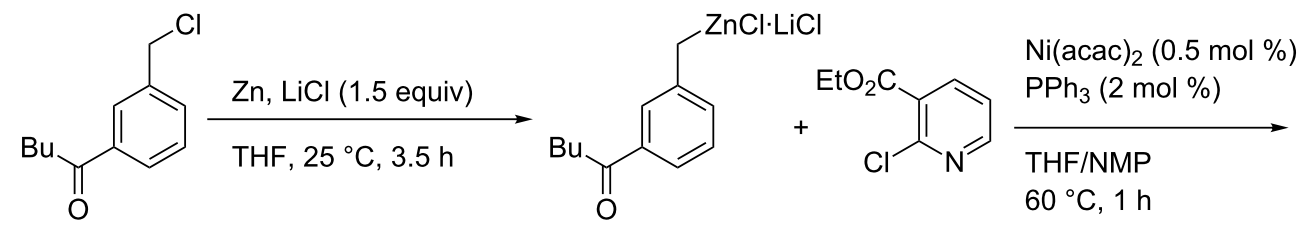

34<smiles>CCOC(=O)c1cccnc1Cc1cccc(C(=O)CC(C)C)c1</smiles>

36: $90 \%$ 
rides or bromides in the presence of $\mathrm{LiCl}$. However, arylmagnesium reagents are compatible with fewer functional groups. Thus, methyl esters react rapidly with arylmagnesium reagents at $0{ }^{\circ} \mathrm{C}$. In order to solve this problem, we have performed a Barbier-type preparation of aryl and heteroaryl zinc reagents by treating the aryl bromide or chloride with magnesium turnings in the presence of zinc chloride and $\mathrm{LiCl}$. Under these conditions, the relatively unreactive aryl bromides and chlorides readily react. Furthermore, sensitive functionalities are tolerated since the reactive arylmagnesium species generated is immediately trapped with zinc chloride (Scheme 7) [22]. Thus, methyl 3-bromobenzoate (37) reacts with magnesium powder in the presence of $\mathrm{LiCl}$ ( 1.5 equiv) and $\mathrm{ZnCl}_{2}$ (1.1 equiv) to provide the intermediate magnesium species $\mathbf{3 8}$, which is immediately trapped with $\mathrm{ZnCl}_{2}$ leading to the zinc reagent 39 in high yields. Subsequent Pd-catalyzed cross-coupling of $\mathbf{3 9}$ with an aryl iodide provides the cross-coupling product $\mathbf{4 0}$ in $79 \%$ yield (Scheme 7) [22].
1.3 Preparation of heteroaryl zinc reagents by direct zincation of heterocyclic compounds using the new zinc base $\mathrm{TMP}_{2} \mathrm{Zn} \cdot 2 \mathrm{MgCl}_{2} \cdot 2 \mathrm{LiCl}(\mathbf{4 2})$

The preparation of zinc reagents by a directed deprotonation was of limited use as no soluble zinc base was available $[23,24]$. We found that the treatment of commercially available $\mathrm{TMPMgCl} \cdot \mathrm{LiCl}(\mathbf{4 1})$ [25-27] with $\mathrm{ZnCl}_{2}$ (0.5 equiv) at $25^{\circ} \mathrm{C}$ provides the new base $\mathrm{TMP}_{2} \mathrm{Zn} \cdot 2 \mathrm{MgCl}_{2} \cdot 2 \mathrm{LiCl}$ (42) [28]. All three metals $\mathrm{Zn}, \mathrm{Mg}$ and $\mathrm{Li}$ are important in this mixed base [29]. The role of $\mathrm{LiCl}$ is to increase the solubility of the base, the role of $\mathrm{MgCl}_{2}$ is to increase its reactivity and the role of zinc is essential since it confers to this base an exceptional chemoselectivity (Scheme 8). Thus, the 1,3,4-oxadiazole $\mathbf{4 3}$ is readily converted to the zinc reagent 44 by the reaction with $\mathrm{TMP}_{2} \mathrm{Zn} \cdot 2 \mathrm{MgCl}_{2} \cdot 2 \mathrm{LiCl}\left(\mathbf{4 2}, 0.55\right.$ equiv; $\left.25^{\circ} \mathrm{C}, 20 \mathrm{~min}\right)$. It should be noted that both TMP-moieties are used and that no fragmentation of this sensitive heterocycle is observed, as is the case for the corresponding Mg- and Li-derivatives.

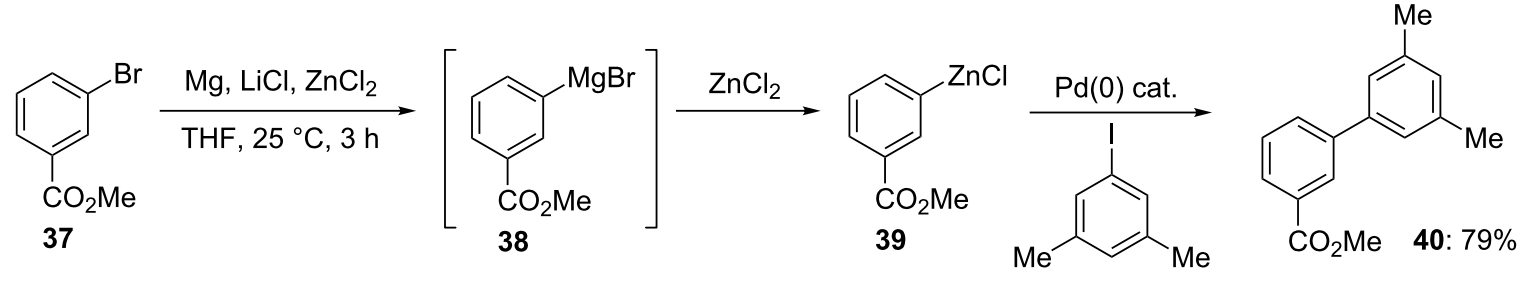

Scheme 7: In situ generation of arylzinc reagents using $\mathrm{Mg}$ in the presence of $\mathrm{LiCl}$ and $\mathrm{ZnCl}_{2}$.<smiles>CN1C(C)(C)CCCC1(C)Cl</smiles>

$\frac{\mathrm{ZnCl}_{2}(0.5 \text { equiv })}{\mathrm{THF}, 25^{\circ} \mathrm{C}, 15 \mathrm{~h}}$

41: $\mathrm{TMPMgCl} \cdot \mathrm{LiCl}$

$\mathrm{TMP}_{2} \mathrm{Zn} \cdot 2 \mathrm{MgCl}_{2} \cdot 2 \mathrm{LiCl}$<smiles>c1ccc(-c2nnco2)cc1</smiles>

43<smiles>O=c1ccc2ccccc2o1</smiles>

46 $\underset{\text { THF, } 25^{\circ} \mathrm{C}, 20 \mathrm{~min}}{\longrightarrow}$<smiles>[Z20]c1nnc(-c2ccccc2)o1</smiles>

44

$\mathrm{TMP}_{2} \mathrm{Zn} \cdot 2 \mathrm{MgCl}_{2} \cdot 2 \mathrm{LiCl}$ (42, 0.55 equiv) $\mathrm{THF}, 25^{\circ} \mathrm{C}, 4 \mathrm{~h}$<smiles>[R]c1cc2ccccc2oc1=O</smiles>
47<smiles>CC1(C)CCCC(C)(C)N1[Z20](=O)CCl</smiles>

42: $\mathrm{TMP}_{2} \mathrm{Zn} \cdot 2 \mathrm{MgCl}_{2} \cdot 2 \mathrm{LiCl}>95 \%$<smiles>O=S(=O)(O)c1ccccc1</smiles><smiles>c1ccc(Sc2nnc(-c3ccccc3)o2)cc1</smiles>

45: $75 \%$<smiles>CCOC(=O)c1ccc(-c2cc3ccccc3oc2=O)cc1</smiles>

48: $83 \%$ 
After a reaction of the heterocyclic zinc reagent 44 with $\mathrm{PhSO}_{2} \mathrm{SPh}$ the corresponding thio-derivative $\mathbf{4 5}$ is obtained in $75 \%$ yield. Coumarine (46) can be directed zincated leading to the zinc reagent 47. After a Negishi cross-coupling with an aromatic iodide, the substituted coumarine $\mathbf{4 8}$ is obtained in $83 \%$ yield (Scheme 8 and Supporting Information File 1, Procedure 3) [28]. This procedure tolerates most of the important functional groups in organic chemistry. Thus, the zincation of the formyl-substituted indole 49 is complete within $45 \mathrm{~min}$ at $25{ }^{\circ} \mathrm{C}$ leading to the zinc reagent $\mathbf{5 0}$. After allylation, the $2,3-$ disubstituted indole $\mathbf{5 1}$ is obtained in $71 \%$ yield (Scheme 9 ). Similarly, 2-nitrobenzofuran (52) is zincated without reacting with the nitro group, leading to the nitro-substituted zinc reagent 53. After allylation, the benzofuran $\mathbf{5 4}$ is obtained in $80 \%$ yield. The polyfunctional pyridine $\mathbf{5 5}$ is zincated with $\mathrm{TMP}_{2} \mathrm{Zn} \cdot 2 \mathrm{MgCl}_{2} \cdot 2 \mathrm{LiCl}$ (42) leading to the zinc reagent 56. Subsequent allylation furnishes the trisubstituted pyridine $\mathbf{5 7}$ in $80 \%$ yield (Scheme 9) [28].

In some cases, the zincation using $\mathrm{TMP}_{2} \mathrm{Zn} \cdot 2 \mathrm{MgCl}_{2} \cdot 2 \mathrm{LiCl}$ (42) is slow and requires long reaction times. This is the case for benzofuran (58), which requires 9 days at $25^{\circ} \mathrm{C}$ for a complete zincation in position 2 leading to $\mathbf{5 9}$. The reaction time can be dramatically decreased by means of microwave irradiation. Under these conditions, the zincation is complete within $1 \mathrm{~h}$ at $120^{\circ} \mathrm{C}$ (Scheme 10). Similarly, the functionalized pyridine 61<smiles>Cn1cc(C=O)c2ccccc21</smiles>

49<smiles>O=[N+]([O-])c1cc2ccccc2o1</smiles>

52

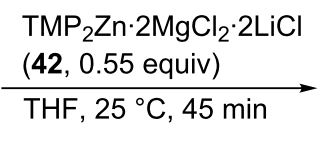

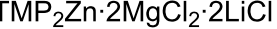
(42, 0.55 equiv) THF, $-25^{\circ} \mathrm{C}, 1.5 \mathrm{~h}$<smiles>O=[N+]([O-])c1cccnc1Cl</smiles>

$\mathrm{TMP}_{2} \mathrm{Zn} \cdot 2 \mathrm{MgCl}_{2} \cdot 2 \mathrm{LiCl}$ (42, 0.55 equiv) THF, $-40^{\circ} \mathrm{C}, 1.5 \mathrm{~h}$<smiles>O=[N+]([O-])c1ccnc(Cl)c1</smiles>

56<smiles>ClC1C=CCCC1</smiles>

53

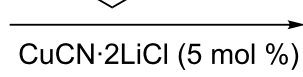

CuCN.2LiCl (5 mol \%)<smiles>C=CCc1c(C=O)c2ccccc2n1C</smiles>

51: $71 \%$<smiles>O=[N+]([O-])c1oc2ccccc2c1C1C=CCCC1</smiles>

54: $80 \%$<smiles>O=[N+]([O-])c1c(C2C=CCCC2)ccnc1Cl</smiles>

57: $80 \%$

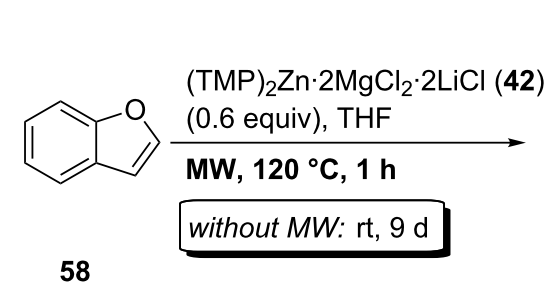

58

$(\mathrm{TMP})_{2} \mathrm{Zn} \cdot 2 \mathrm{MgCl}_{2} \cdot 2 \mathrm{LiCl}(42)$<smiles>CCOC(=O)c1cccnc1Cl</smiles>
(0.6 equiv), THF

$\mathrm{MW}, 80^{\circ} \mathrm{C}, 1 \mathrm{~h}$<smiles>[SnH3]Oc1ccc(-c2cc3ccccc3o2)cc1</smiles>

60: $95 \%$

61<smiles>CCOC(=O)c1cccnc1Cl</smiles>

62
59

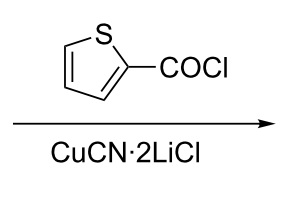<smiles>CCOC(=O)c1c(C(=O)c2cccs2)ccnc1Cl</smiles>

63: $80 \%$ 
is zincated within $1 \mathrm{~h}$ at $80^{\circ} \mathrm{C}$ under microwave irradiation leading to 62 . The success of this procedure is a result of the high thermal stability of organozinc reagents. A Pd-catalyzed cross-coupling of $\mathbf{5 9}$ or a copper(I)-mediated acylation of $\mathbf{6 2}$ affords the products 60 and 63 in $80-95 \%$ yield (Scheme 10 and Supporting Information File 1, Procedure 4) [30].

\section{Preparation of heterocyclic magnesium reagents}

Unexpectedly, recent research work from our laboratories showed that the preparation of heteroarylmagnesium reagents is compatible with numerous functional groups [31-33]. There are three important synthetic methods for the preparation of polyfunctional heteroarylmagnesium reagents:

1. the bromine- (or iodine-) magnesium exchange reaction;

2. the direct insertion of magnesium turnings in the presence of $\mathrm{LiCl}$;

3. the direct magneziation of heterocycles using $\mathrm{TMPMgCl} \cdot \mathrm{LiCl}(\mathbf{4 1})$.

Due to the higher polarity of the carbon-magnesium bond, these heterocyclic organometallics are significantly more reactive than the corresponding zinc reagents. This makes their preparation especially important.

\subsection{The preparation of heterocyclic magnesium reagents through a bromine- (or iodine-) magne- sium exchange}

Compared to the halogen/lithium exchange, discovered in 1939 by Wittig and Gilman, the halogen/magnesium exchange is much slower. Whereas aryl and electron-poor unsaturated iodides readily react with $\mathrm{PrMgCl}$ and undergo a metalmetathesis to provide the more stable heteroarylmagnesium reagent (Scheme 11) [34], the reaction of aryl and heteroaryl bromides is slow when $\mathrm{iPrgCl}$ is used as an exchange reagent.

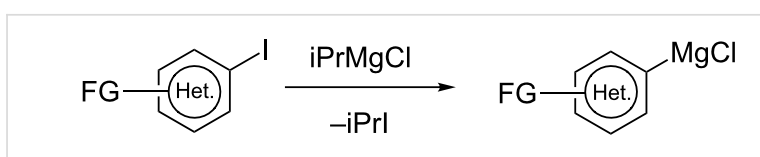

Scheme 11: The I/Mg-exchange as a metal-metathesis reaction.

However, with the aid of the mixed Li/Mg-reagent $i \mathrm{PrMgCl} \cdot \mathrm{LiCl}(64)$, an efficient exchange reaction is also effective with a wide range of aryl and heteroaryl bromides [3133,35]. This reagent (64) is commercially available as an approx. $1 \mathrm{M}$ THF solution from Chemetall $\mathrm{GmbH}$ [27]. Recently, we have applied this exchange reaction for the regioselective functionalization of quinolines. Thus, the 2,3-dibromoquinoline (65) is regioselectively converted to the 3-magnesiated quinoline derivative 66. Using the same exchange reagent, $\mathrm{iPrMgCl} \cdot \mathrm{LiCl}(\mathbf{6 4})$ and 2,4-dibromoquinoline (68), it is now possible to obtain the 4-magnesiated quinoline 69. All these magnesiations proceed at low temperature $\left(-50{ }^{\circ} \mathrm{C}\right.$ to $-78^{\circ} \mathrm{C}$ ) and are complete within $2 \mathrm{~h}$ reaction time. After reaction with $\mathrm{TsCN}$, the corresponding nitriles $\mathbf{6 7}$ and $\mathbf{7 0}$ were obtained in $84-85 \%$ yield (Scheme 12 and Supporting Information File 1, Procedure 5) [36].

The rate of the $\mathrm{Br} / \mathrm{Mg}$-exchange depends on the electronic density of the heterocyclic rings. The electron-poor ring systems undergo considerably faster $\mathrm{Br} / \mathrm{Mg}$-exchange reactions than do heterocyclic ring systems bearing electron-rich substituents [31-35]. Therefore, in order to achieve a regioselective exchange with the very electron-poor tribromoquinoline 73, it was necessary to reduce the reactivity of the exchange reagent and thus, to switch from iPrMgCl$\cdot \mathrm{LiCl}(64)$ to the less reactive mesitylmagnesium reagent $\mathrm{Mes} \mathrm{MgCl} \cdot \mathrm{LiCl}$ (71). This reagent is readily prepared by the reaction of mesityl bromide with magnesium turnings in the presence of $\mathrm{LiCl}\left(25^{\circ} \mathrm{C}, 12 \mathrm{~h}\right.$; Scheme 13) [36]. The lower reactivity of 71 allows a perfectly regioselective exchange reaction of $\mathbf{7 3}$, to afford the 3-magnesi-
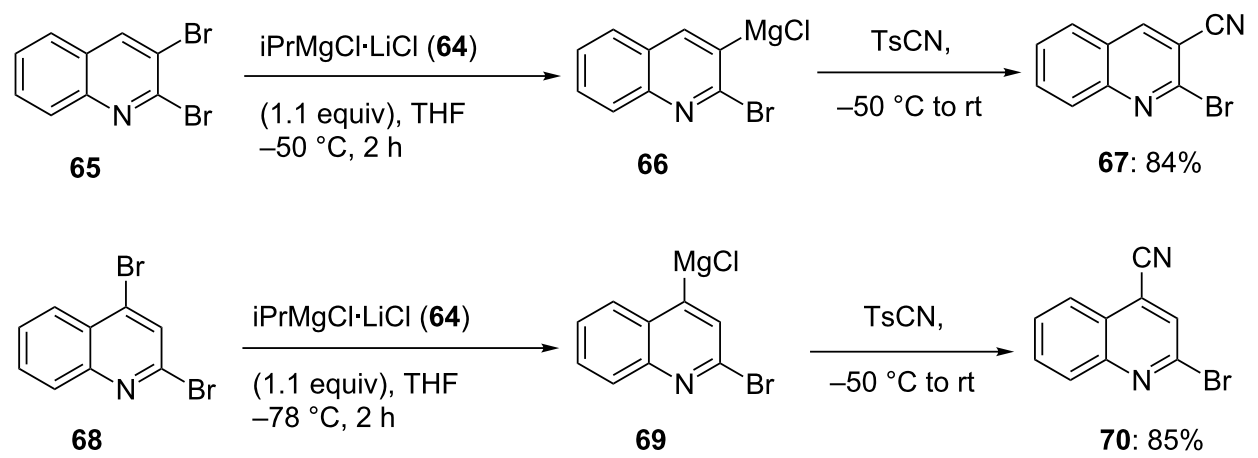
ated quinoline $\mathbf{7 4}$ only. A differentiation between the reactivity of a 3-bromo- and a 4-bromo-substituted quinoline is more difficult and even the use of the less reactive exchange reagent $\mathrm{MesMgBr} \cdot \mathrm{LiCl}$ is not satisfactory. This reactivity can be further tuned: First by preparing the dimesitylmagnesium reagent $\mathrm{Mes}_{2} \mathrm{Mg} \cdot 2 \mathrm{LiBr}$ (which has a higher reactivity than 71) and then by adding a complexation reagent, such as TMEDA (1 equiv), which considerably lowers the reactivity $[37,38]$. The new resulting reagent $\mathrm{Mes}_{2} \mathrm{Mg} \cdot 2 \mathrm{LiBr} \cdot \mathrm{TMEDA}(72)$ now reacts smoothly with 3,4-dibromoquinoline (76) providing selectively the 3-magnesiated 4-bromoquinoline 77. The quenching of $\mathbf{7 4}$ and 77 with $\mathrm{TsCN}$ and $\mathrm{PhSO}_{2} \mathrm{SMe}$, respectively, leads to the regioselectively functionalized quinolines $\mathbf{7 5}$ and $\mathbf{7 8}$ in $79-88 \%$ yield (Scheme 13) [36].

This fine tuning is usually not necessary and numerous $\mathrm{Br} / \mathrm{Mg}$ exchange reactions making use of the commercially available reagent $\mathrm{iPrMgCl} \cdot \mathrm{LiCl}(64)$ have been reported in the literature [31-34,39].

The use of $\mathrm{PrMgCl} \cdot \mathrm{LiCl}$ also proves to be very practical for the generation of polyfunctional alkenylmagnesium reagents, which react only slowly with $\mathrm{PrMgCl}[40,41]$, as well as for the preparation of arylmagnesium reagents bearing sensitive functionalities, such as triazene. Thus, aryl iodide $\mathbf{7 9}$ is treated with iPrMgCl$\cdot \mathrm{LiCl}(64)$ at $-40{ }^{\circ} \mathrm{C}$ for $1 \mathrm{~h}$ leading to an intermediate magnesium reagent, which after transmetalation to the corresponding zinc reagent using $\mathrm{ZnBr}_{2}$ provides, after Negishi crosscoupling reaction with the bromoquinoline 80, the polyfunctinal triazene $\mathbf{8 1}$ in $75 \%$ yield. The conversion of the triazene functionality to an azide group is readily achieved by treating 81 with $\mathrm{NaN}_{3} / \mathrm{BF}_{3} \cdot \mathrm{OEt}_{2}-\mathrm{CF}_{3} \mathrm{CO}_{2} \mathrm{H}$ in $\mathrm{CH}_{2} \mathrm{Cl}_{2}$ leading to the aryl azide $\mathbf{8 2}$ in $78 \%$ yield. Heating of $\mathbf{8 2}$ in mesitylene at reflux for $6 \mathrm{~h}$ provides ellipticine 83, a potent antitumor agent in $57 \%$ yield (Scheme 14) [42].

The structural variations of pyrimidines and purines are very important for the design of antiviral agents. The amination of this class of heterocycles is of particular importance. Recently, we developed an oxidative amination procedure for lithium derivatives using chloranil as oxidation agent [43]. We applied this procedure in the preparation of a CDK inhibitor, purvalanol A (84). Thus, an I/Mg-exchange on the purine 85 with iPrMgCl$\cdot \mathrm{LiCl}$ (64), followed by the transmetalation to the corresponding copper derivative with $\mathrm{CuCl} \cdot 2 \mathrm{LiCl}$, and the addition of the lithiated aniline derivative $\mathbf{8 6}$, furnishes the amidocuprate $\mathbf{8 7}$. In the presence of chloranil amidocuprate $\mathbf{8 7}$ undergoes an oxidative coupling providing the adenine derivative 88 in $71 \%$ yield. A treatment with D-valinol (89) affords the desired CDK inhibitor, purvalanol A (84) in $65 \%$ yield (Scheme 15) [44].

\subsection{The preparation of polyfunctional heterocyclic magnesium reagents by the insertion of $\mathrm{Mg}$ in the presence of $\mathrm{LiCl}$}

The presence of $\mathrm{LiCl}$ facilitates greatly the insertion of many metals into carbon-halogen bonds and avoids the use of expensive activated forms of $\mathrm{Mg}$, such as "Rieke-magnesium". This property of $\mathrm{LiCl}$ for accelerating the insertion of $\mathrm{Mg}$ to organic halides has found numerous applications in the preparation of new polyfunctional arylmagnesium reagents. Thus, the rapid reaction of $\mathrm{Mg} / \mathrm{LiCl}$ with aryl bromides 90,93 and 96 allows an expeditive synthesis of the new arylmagnesium derivatives $\mathbf{9 1}$, 94 and 97. Quenching with typical electrophiles provides the expected products $\mathbf{9 2 , 9 5}$ and 98 in 76-95\% yield (Scheme 16) $[22,45]$.

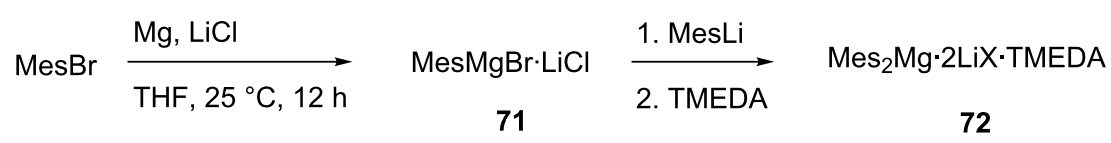
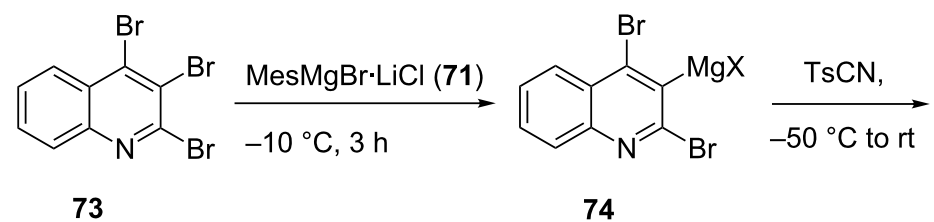

74<smiles>N#Cc1c(Br)nc2ccccc2c1Br</smiles><smiles>[B]c1cnc2ccccc2c1Br</smiles>

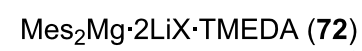
$-10^{\circ} \mathrm{C}, 6 \mathrm{~h}$<smiles>COOS(=O)(=O)c1cccc2ncc(N(C)c3ccccc3)c(Br)c12</smiles>

75: $88 \%$<smiles>CSc1cnc2ccccc2c1Br</smiles>

78: $79 \%$ 
<smiles>Ic1ccccc1N=NN1CCCC1</smiles>

79
1) $\mathrm{irMgCl} \cdot \mathrm{LiCl}$

(64), $-40^{\circ} \mathrm{C}, 1 \mathrm{~h}$

2) $\mathrm{ZnBr}_{2}$, $\mathrm{THF}$

3) $\mathrm{Pd}\left(\mathrm{PPh}_{3}\right)_{4}$ cat. reflux, $4 \mathrm{~h}$<smiles>Cc1cc(Br)c2c3c1C=NC3=C2[N+](=O)[O-]</smiles>

$\prod_{\substack{1 \\ N^{\prime}}}$<smiles>CN=Nc1ccccc1-c1cc(C)c2ccncc2c1[N+]([O-])([O-])O</smiles>

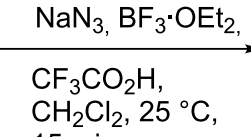
$\mathrm{CH}_{2} \mathrm{Cl}_{2}, 25^{\circ} \mathrm{C}$, 15 min<smiles>Nc1ccccc1-c1cc([N+](=O)[O-])c2ccncc2c1[N+](=O)[O-]</smiles>

81: $75 \%$

82: $78 \%$

82

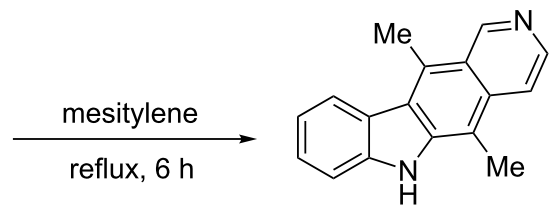

83: ellipticine; $57 \%$<smiles>CC(C)n1cnc2c(I)nc(Cl)nc21</smiles>

85
1) $\mathrm{iPrMgCl} \cdot \mathrm{LiCl}(64)$

$-60{ }^{\circ} \mathrm{C}, 0.3 \mathrm{~h}$

2) $\mathrm{CuCl} \cdot 2 \mathrm{LiCl}$<smiles>CCOCCN(CC)CC</smiles>

86<smiles>CC(C)n1cnc2c(CN([13CH3])[13CH3])nc(Cl)nc21</smiles>

87
1) chloranil

-80 to $-50{ }^{\circ} \mathrm{C}, 12 \mathrm{~h}$

2) TBAF

$25^{\circ} \mathrm{C}, 0.3 \mathrm{~h}$

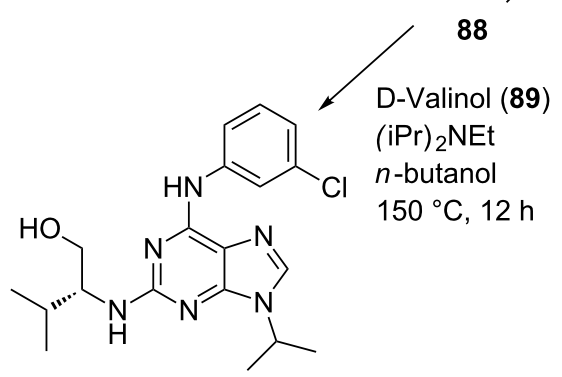

84: purvalanol $\mathrm{A} ; 65 \%$

Scheme 15: An oxidative amination leading to the biologically active adenine, purvalanol $A(84)$.

Remarkably, this insertion proceeds also with readily available and inexpensive aryl and heteroaryl chlorides, such as $\mathbf{9 9 ,}, \mathbf{1 0 2}$ and $\mathbf{1 0 5}$, providing the functionalized magnesium reagents $\mathbf{1 0 0}$, 103 and 106 under mild conditions. The cross-coupling reaction of these Grignard reagents and transmetalation to zinc organometallics with $\mathrm{ZnCl}_{2}$ affords the expected products 101, 104 and 107 in 69-82\% (Scheme 17 and Supporting Information File 1, Procedure 6) $[9,22]$.

\subsection{Preparation of polyfunctional heterocyclic}

magnesium reagents by directed magnesation using TMPMgCl. $\mathrm{LiCl}$ (41) or $\mathrm{TMP}_{2} \mathrm{Mg} \cdot 2 \mathrm{LiCl}$ (129)

The directed magnesiation of aromatic substrates using $\mathrm{TMPMgCl} \cdot \mathrm{LiCl}(\mathbf{4 1})$ constitutes an economical preparation of a range of functionalized arylmagnesium compounds $[25,26]$. Sensitive heterocycles such as pyrimidines can be readily magnesiated with commercially available $\mathrm{TMPMgCl} \cdot \mathrm{LiCl}$ (41) 
Br $\frac{\mathrm{Mg}, \mathrm{LiCl}}{\mathrm{THF}, 0{ }^{\circ} \mathrm{C}, 2 \mathrm{~h}}$

90<smiles>CC(C)(C)Oc1cccc(Br)c1</smiles>

93

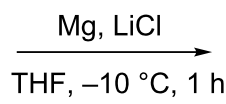<smiles>CC(C)(C)Oc1cccc(N(Br)Br)c1</smiles>

94<smiles>O=C(Cl)N[Mg]Cl</smiles>

2)<smiles>Cl[Hg]Cl</smiles><smiles>Brc1ccc(/N=N/N2CCCC2)c(Br)c1</smiles><smiles>CC1(Br)CCCC1C=O</smiles><smiles>Brc1ccc(N=NN2CCCC2)c(Br)c1</smiles>

96 $25^{\circ} \mathrm{C}, 1.5 \mathrm{~h}$

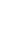

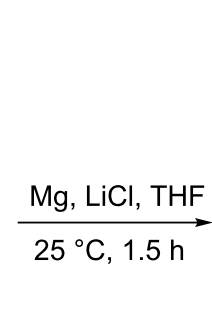

97<smiles>O=Cc1cccc([18F])c1</smiles>

92: $77 \%$<smiles>CC(C)(C)Oc1cccc(C(=O)c2ccc(Cl)cc2)c1</smiles>

95: $95 \%$

Scheme 16: Preparation of polyfunctional arylmagnesium reagents using $\mathrm{Mg}$ in the presence of $\mathrm{LiCl}$.

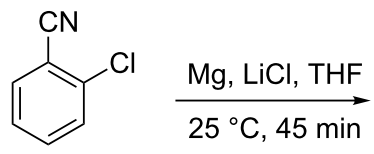

99<smiles>N#Cc1ccccc1N(Cl)Cl</smiles>

100
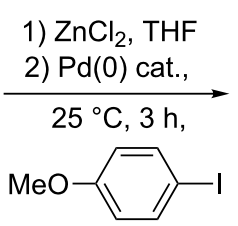<smiles>CC(C)(C)C(O)c1ccc(N=NN2CCCC2)c(Br)c1</smiles>

98: $76 \%$<smiles>N#Cc1ccc(Cl)cc1</smiles>

102<smiles>CC(C)(C)COC(=O)c1c(Cl)sc(Cl)c1C(=O)OC(C)(C)C</smiles>

105<smiles>N#Cc1ccc(N(Cl)Cl)cc1</smiles>

1) $\mathrm{ZnCl}_{2}, \mathrm{THF}$

2) $\operatorname{Pd}(0)$ cat.,

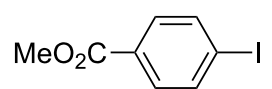<smiles>CC(=O)c1ccc(-c2ccc(C#N)cc2)cc1</smiles>

104: $69 \%$

Scheme 17: Preparation of polyfunctional magnesium reagents starting from organic chlorides.

[27]. Thus, electron-poor 2-bromopyrimidine (108) is converted within $1.5 \mathrm{~h}$ at $-55^{\circ} \mathrm{C}$ in the presence of $\mathrm{TMPMgCl} \cdot \mathrm{LiCl}(\mathbf{4 1})$ to the corresponding magnesium reagent 109. A low reaction temperature is required in this case, since the sensitive heterocycle 108 undergoes ring addition reactions at temperatures above $-30{ }^{\circ} \mathrm{C}$. Quenching of the 4-magnesiated pyrimidine 109 with $\mathrm{MeSO}_{2} \mathrm{SMe}$ provides the thiomethyl derivative 110 in $81 \%$ yield (Scheme 18 and Supporting Information File 1, Procedure 7) [46].

The presence of a thiomethyl substituent considerably increases the electron density of this pyrimidine and the addition of a 


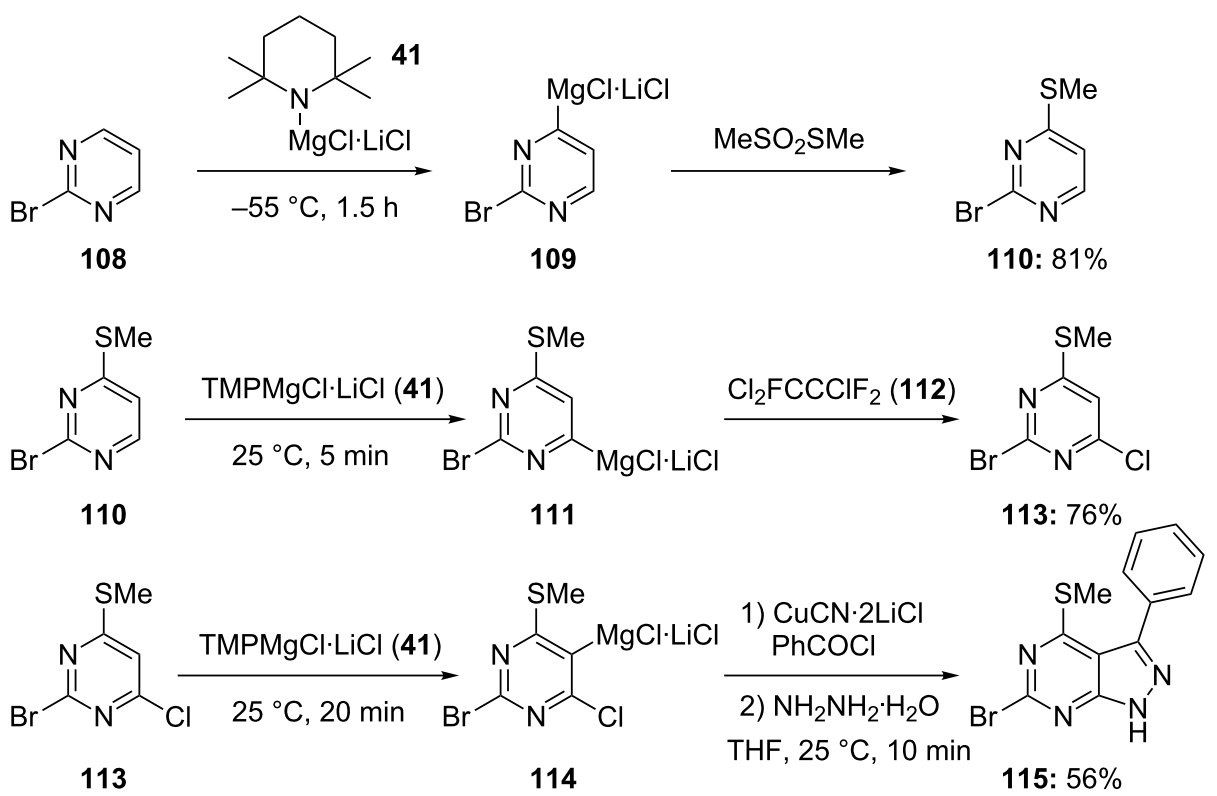

Scheme 18: Selective multiple magnesiation of the pyrimidine ring.

Grignard reagent to this heterocycle can no longer occur. Therefore, a subsequent magnesiation of $\mathbf{1 1 0}$ with $\mathrm{TMPMgCl} \cdot \mathrm{LiCl}$ ( 1.0 equiv) can be performed at $25^{\circ} \mathrm{C}$. After 5 min reaction time at this temperature, the resulting 6-magnesiated pyrimidine 111 is obtained quantitatively. Quenching of $\mathbf{1 1 1}$ with $\mathrm{Cl}_{2} \mathrm{FCCClF}_{2}$ (112) provides the trisubstituted pyrimidine 113 in $76 \%$ yield. A final functionalization in position 5 is readily achieved by treating $\mathbf{1 1 3}$ with a further equivalent of
$\mathrm{TMPMgCl} \cdot \mathrm{LiCl}\left(41,25^{\circ} \mathrm{C}, 20 \mathrm{~min}\right)$ providing the 5 -magnesiated pyrimidine 114. Quenching with benzoyl chloride furnishes the expected unsaturated ketone, which by treatment with hydrazine $\left(\mathrm{NH}_{2}-\mathrm{NH}_{2} \cdot \mathrm{H}_{2} \mathrm{O}\right.$, THF, $\left.25{ }^{\circ} \mathrm{C}, 10 \mathrm{~min}\right)$ leads to the pyrazolopyrimidine $\mathbf{1 1 5}$ in $56 \%$ overall yield (Scheme 18) [46]. A similar approach has been used to prepare the p38 kinase inhibitor 119 in $72 \%$ overall yield, as well as the sPLA2 inhibitor 123, in a short reaction sequence (Scheme 19) [46].<smiles>CSc1nc(Cl)cc(Cl)n1</smiles>

116<smiles>CSc1nc(Cl)cc(Cl)n1</smiles>

116<smiles>CSc1nc(Cl)c(I)c(NBr)n1</smiles>

121
1) $\mathrm{TMPMgCl} \cdot \mathrm{LiCl}$ (41) (1.1 equiv), THF, rt, $20 \mathrm{~min}$

2)<smiles>O=C(Cl)c1ccccc1Cl</smiles>

(2.0 equiv), rt, $1 \mathrm{~h}$

1) $\mathrm{TMPMgCl} \cdot \mathrm{LiCl}$

(41) (1.1 equiv)

THF, rt, $20 \mathrm{~min}$

2) $I_{2}$ (1.5 equiv)

THF, rt, 20 min

1) $\mathrm{Pd}(\mathrm{dba})_{2}(3 \mathrm{~mol} \%)$, $\mathrm{P}(\mathrm{o} \text {-furyl })_{3}(6 \mathrm{~mol} \%)$, Cul $\left(4 \mathrm{~mol}_{\%}\right), \mathrm{NEt}_{3}$

2) 1-butyne (2.0 equiv) $\mathrm{MeS}$ $50{ }^{\circ} \mathrm{C}, 1 \mathrm{~h}$
122: $98 \%$<smiles>CSc1nc(Cl)c(C(=O)c2ccccc2Cl)c(Cl)n1</smiles>

118<smiles>CS(C)(=O)(O)c1nc(Cl)c(I)c(Cl)n1</smiles>

120: $90 \%$

$\mathrm{BnNH}_{2}$ (1.7 equiv) THF, rt, $20 \mathrm{~min}$<smiles>CCC#Cc1c(Cl)nc(SCC(C)(C)C)nc1NCc1ccccc1</smiles><smiles>CS(=O)(=O)c1nc(Cl)c2c(-c3ccccc3Cl)n[nH]c2n1</smiles>

119: $72 \%$ 
Using $\mathrm{TMPMgCl} \cdot \mathrm{LiCl}(\mathbf{4 1})$, it is possible to prepare fully substituted indoles, such as $\mathbf{1 2 8}$ (Scheme 20) [47]. Thus, starting from the aniline $\mathbf{1 2 4}$, an ortho-directed chlorination with $\mathrm{N}$-chlorosuccinimide at $90{ }^{\circ} \mathrm{C}$ followed by an iodination with iodine and $\mathrm{Ag}_{2} \mathrm{SO}_{4}$ furnishes the tetrasubstituted aniline 125. Protection of the free amino-group followed by a Negishireaction provides the scaffold $\mathbf{1 2 6}$ in $80 \%$ yield (Scheme 20).

Successive magnesiations at the positions 5 and 3 of the tetrasubstituted anilines 126 with TMPMgCl$\cdot \mathrm{LiCl}(\mathbf{4 1})$ can be performed. The strongly electron-withdrawing properties of the chloro-substituent favor a metalation at position 5. After the addition of pivaldehyde, the subsequent addition of a second equivalent of $\mathrm{TMPMgCl} \cdot \mathrm{LiCl}\left(41 ;-30{ }^{\circ} \mathrm{C}, 1.5 \mathrm{~h}\right)$ allows now a magnesiation in position 3. Quenching with $\mathrm{TsCN}$ and deprotection of the silylated aniline with $\mathrm{KF}$ and $\mathrm{HCl}$ furnishes the hexa-substituted aniline 127 in $76 \%$ overall yield. Potassium hydride mediated ring closure in NMP [48] affords the desired indole $\mathbf{1 2 8}$ in 96\% yield (Scheme 20) [47].

In some cases, $\mathrm{TMPMgCl} \cdot 2 \mathrm{LiCl}(\mathbf{4 1})$ is not reactive enough to achieve a magnesiation in a reasonable time frame. We therefore prepared a more reactive bis-TMP base, $\mathrm{TMP}_{2} \mathrm{Mg} \cdot 2 \mathrm{LiCl}$ (129), by mixing TMPLi with the commercially available base 41 [49]. The metalation temperature using such a base is low enough that functional groups such as a Boc-group or an aryl ketone are readily tolerated. Thus, the Boc-substituted benzophenone 130 reacts with $\mathrm{TMP}_{2} \mathrm{Mg} \cdot 2 \mathrm{LiCl}$ (1.1 equiv, $-20^{\circ} \mathrm{C}, 4 \mathrm{~h}$ ) providing the expected aryl magnesium amide $\mathbf{1 3 1}$, which after a copper-mediated benzoylation leads to the 1,2,3trisubstituted diketone $\mathbf{1 3 2}$ in $\mathbf{7 2 \%}$ yield. This reagent allows a smooth functionalization of heterocycles such as the dicarbethoxypyridine $\mathbf{1 3 3}$, which is readily magnesiated with the base $\mathbf{1 2 9}$ at $-40{ }^{\circ} \mathrm{C}$ within $3 \mathrm{~h}$, leading to $\mathbf{1 3 4}$. After a Negishi cross- coupling reaction with an aromatic iodide, the 2-functionalized pyridine $\mathbf{1 3 5}$ is obtained in 73\% yield (Scheme 21, Procedure 8) [49].

\section{New Pd- and Ni-cross-coupling procedures}

Although numerous cross-coupling methods have been recently described in the literature [50-52], there is still the need for new convenient procedures. We would like to focus on the chemoselectivity problem in cross-couplings in this short section and report two protocols recently developed in our laboratories:

1. A chemoselective Negishi cross-coupling protocol tolerating acidic hydrogen atoms.

2. A chemoselective Kumada cross-coupling based on a new radical mechanism.

\subsection{Chemoselective Negishi cross-coupling using substrates bearing acidic hydrogen atoms}

The ability to perform cross-couplings is certainly one of the most versatile functions of heterocyclic zinc intermediates. Recently, we have shown that $\mathrm{NiCl}_{2}(0.05 \mathrm{~mol} \%)$ constitutes an economical method for performing Negishi cross-couplings $[18,19]$, however, it does not solve the problem of the moderate chemoselectivity of organozinc reagents towards substrates bearing acidic hydrogen atoms, such as $\mathrm{N}-\mathrm{H}$ and $\mathrm{O}-\mathrm{H}$ bonds. This is an important limitation of the Negishi cross-coupling, especially compared to the Suzuki cross-coupling based on boronic acid derivatives, which are much more tolerant toward acidic NH- and $\mathrm{OH}$-groups. In the course of our studies, we found that by using an active catalyst system, such as S-Phos, developed by S. L. Buchwald [15-17], a smooth cross-coupling can be achieved between benzylic, aromatic and alkyl zinc reagents with substrates bearing an $\mathrm{NH}$ - or an $\mathrm{OH}$-group (Scheme 22) [53,54].

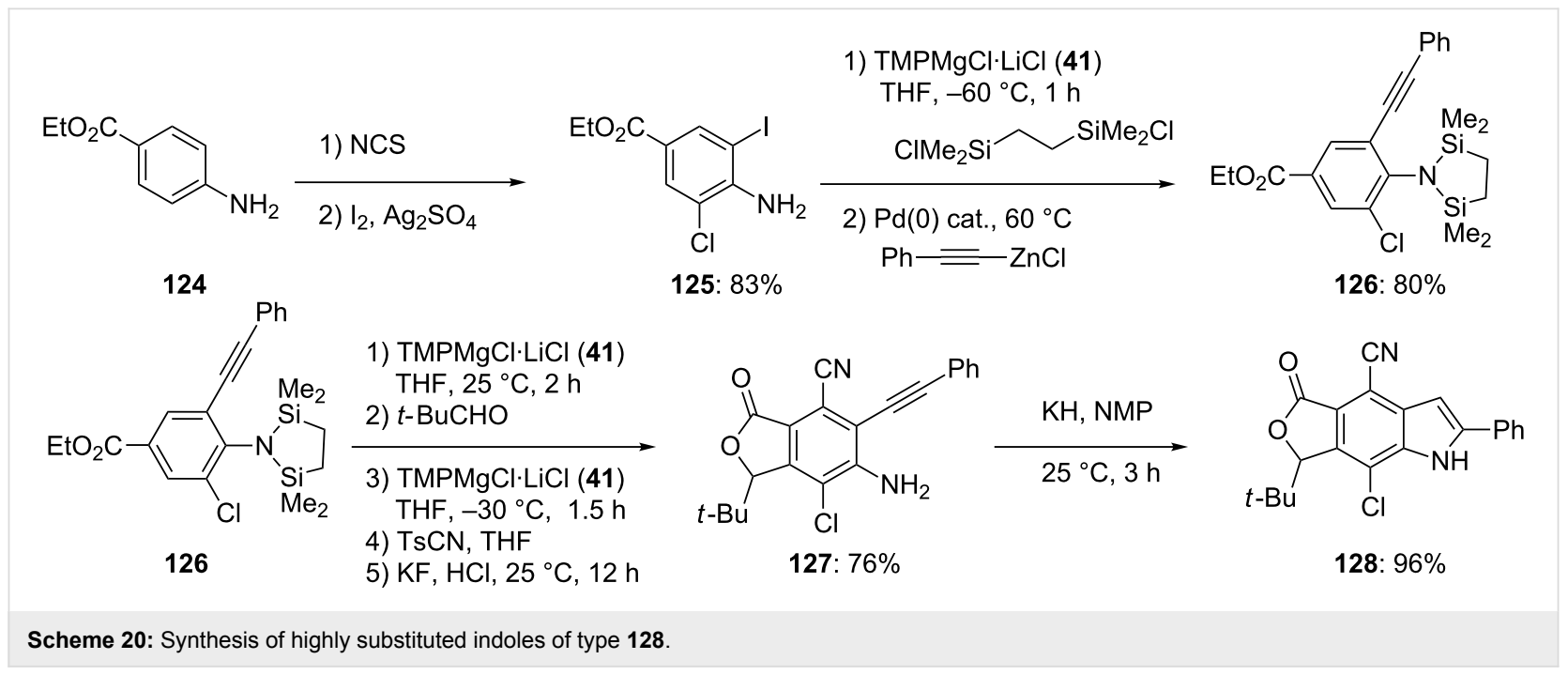




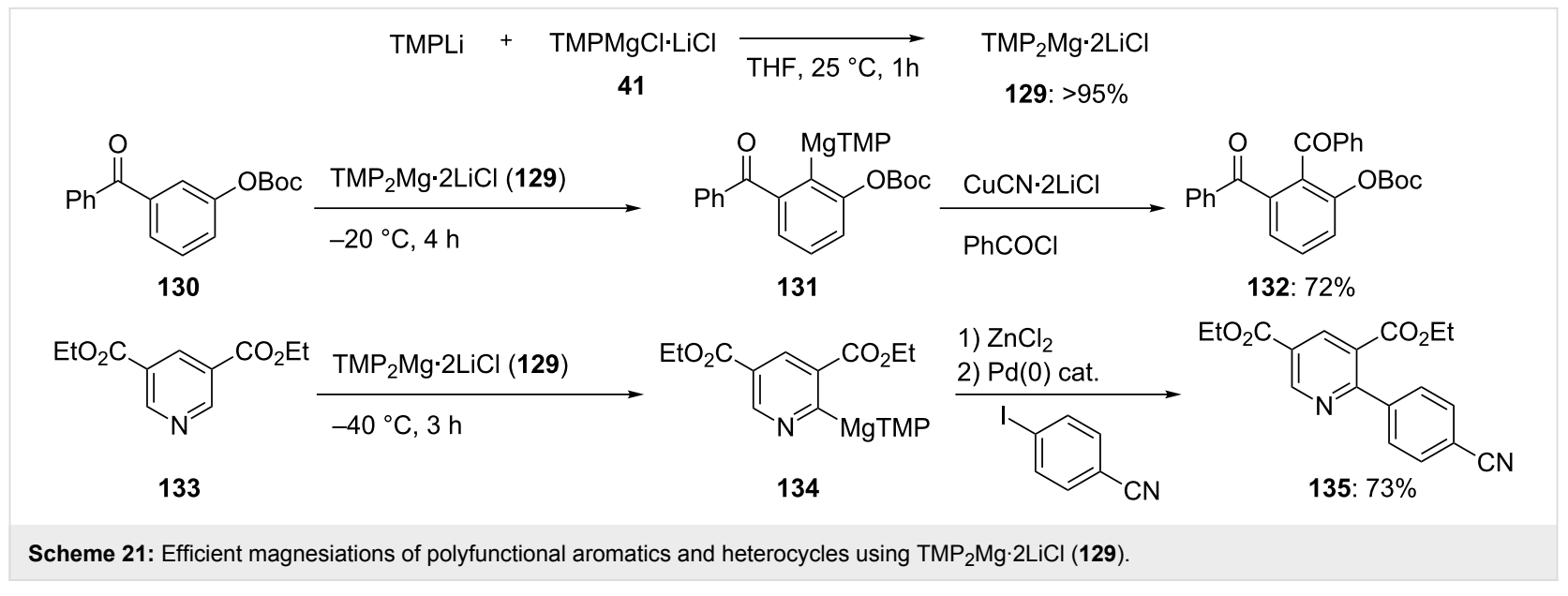

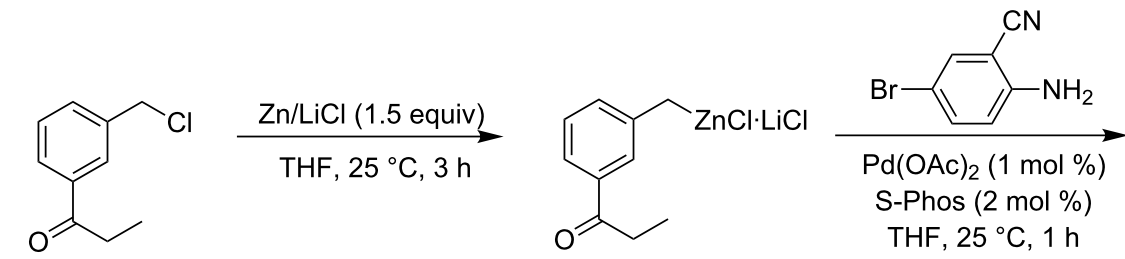

137

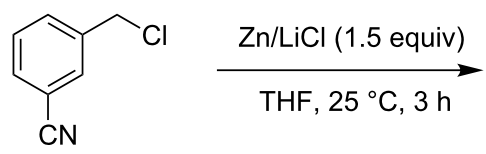

139

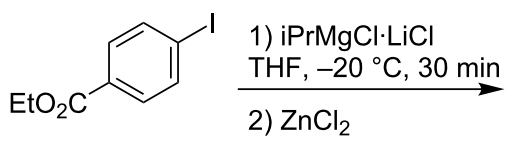

1<smiles>CCOC(=O)c1cccc(CCl)c1</smiles>

145<smiles></smiles>

140<smiles>CCCc1ccc(C(=O)OCC)cc1</smiles>

142

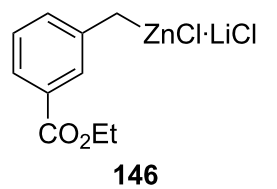

slow addition over $90 \mathrm{~min}$<smiles>CCC(=O)c1cccc(Cc2ccc(N)c(C#N)c2)c1</smiles>

138: $88 \%$<smiles>N#Cc1cccc(Cc2cncc(N)c2)c1</smiles>

141: $90 \%$<smiles>C=C(CNc1ccccc1)c1ccc(C(=O)OCC)cc1</smiles>

$\mathrm{Ph}$

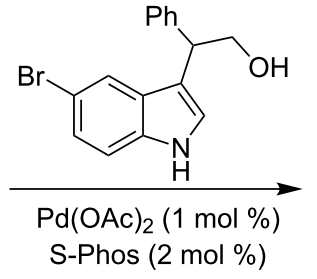

$\mathrm{THF}, 25^{\circ} \mathrm{C}$

THF, $25^{\circ} \mathrm{C}$<smiles>CCOC(=O)c1cccc(Cc2ccc3[nH]cc(C(CO)c4ccccc4)c3c2)c1</smiles>

147: $85 \%$<smiles>CC(O)c1cccc(CCCC#N)c1</smiles>

150: $88 \%$

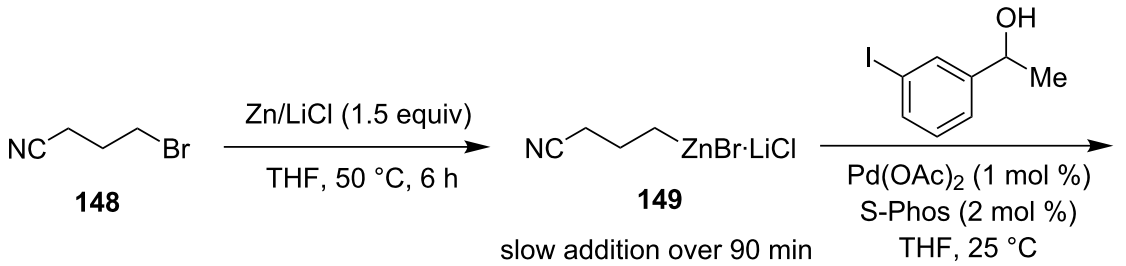

Scheme 22: Negishi cross-coupling in the presence of substrates bearing an $\mathrm{NH}$ - or an $\mathrm{OH}$-group. 
Remarkably, this reaction protocol was extended to substrates bearing an $\alpha$-aminoester moiety, such as $\mathbf{1 5 2}$ providing the cross-coupling product 153 in $85 \%$ yield (Scheme 23 and Supporting Information File 1, Procedure 9) [54].

\subsection{Radical catalyzed Kumada chemoselective cross-coupling}

As aryl- and heteroarylmagnesium reagents are readily available, it would be highly desirable if cross-couplings could be directly realized using these organometallics without the need of further transmetalation to zinc, boron or other metals. However, the disadvantage of this cross-coupling, known in the literature as Kumada cross-coupling $[55,56]$, is that it only proceeds with relatively nonfunctional molecules as the $\mathrm{C}-\mathrm{Mg}$ bond can competitively attack the functional group present in the aromatic or heterocyclic electrophile instead of undergoing the desired cross-coupling. We have found that the presence of iPrI (or another alkyl iodide) catalyzes the Kumada crosscoupling reaction, such that highly reactive functional groups, such as ketones, esters or nitriles, are perfectly tolerated (Scheme 24 and Supporting Information File 1, Procedure 10) $[57,58]$.

The mechanism of the reaction has been shown to be of radical nature, and it affords the cross-coupling products in very short reaction times, often less than $5 \mathrm{~min}$.

\section{$4 \mathrm{MgCl}_{2}$-Enhanced reactivity of functional- ized organozincs towards their addition to aldehydes, ketones and carbon dioxide}

The addition reactions of organometallic reagents to ketones, aldehydes and carbon dioxide are essential transformations in organic synthesis as they provide a convenient access to various<smiles>Cl[GeH]Cl</smiles>

151

1.3 equiv slow addition over $90 \mathrm{~min}$<smiles>COC(=O)C(CO)NC(=O)c1ccc(I)cc1</smiles>

152: $98 \%$ ee
$\mathrm{Pd}(\mathrm{OAc})_{2}(1 \mathrm{~mol} \%)$

S-Phos (2 mol \%)

$\mathrm{THF}, 25^{\circ} \mathrm{C}$<smiles>CC(=O)[C@H](CO)NC(=O)c1ccc(Cc2ccccc2Cl)cc1</smiles>

153: $85 \%,>98 \%$ ee

Scheme 23: Negishi cross-coupling in the presence of a serine moiety.<smiles>CCOC(=O)c1cccc(N(Cl)Cl)c1</smiles>

154
$\frac{\mathrm{iPrMgCl} \cdot \mathrm{LiCl}(64)}{\mathrm{THF},-20{ }^{\circ} \mathrm{C}}$

157<smiles>Cc1c(I)c2ccccc2n1Cc1ccccc1</smiles>

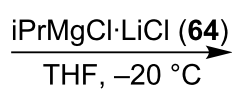
$45 \mathrm{~min}$<smiles>O=C(c1cccc(Br)c1)C1CCCC1</smiles>

155

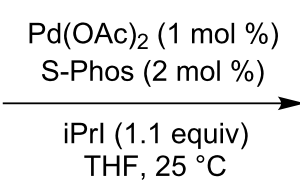

THF, $25^{\circ} \mathrm{C}$<smiles>COc1ncc(C)c(OC)n1</smiles>

158<smiles>Cc1c(C)n(Cc2ccccc2)c2ccccc12</smiles>

161

S-Phos (2 mol \%)<smiles>CCOC(=O)c1cccc(-c2cccc(C(=O)C3CCCC3)c2)c1</smiles>

156: $82 \%$
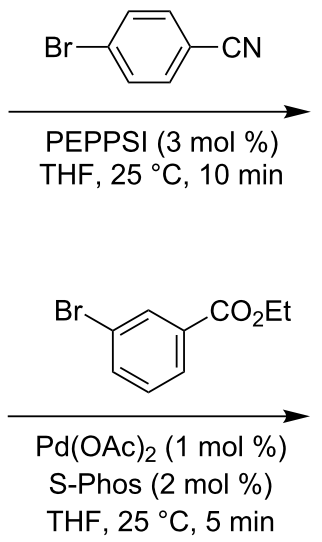

$$
\text { THF }
$$
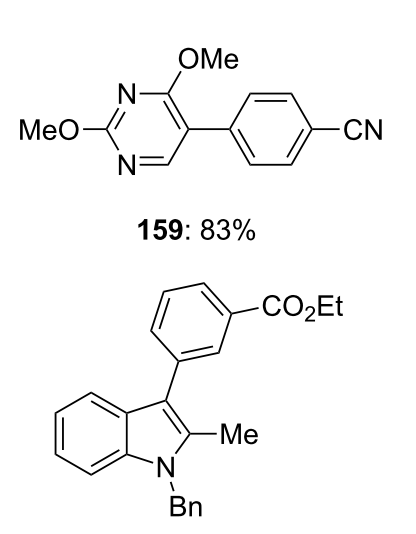

162: $79 \%$

Scheme 24: Radical catalysis for the performance of very fast Kumada reactions. 
types of alcohols or carboxylic acids. Usually, organozinc reagents only react with these types of electrophiles in the presence of catalytic amounts of transition metal salts and in a very limited scope. Recently, we showed that the cheap and nontoxic main group Lewis acid $\mathrm{MgCl}_{2}$ allows smooth addition reactions of different aromatic, heteroaromatic, alkyl and benzylic zinc reagents to various carbonyl derivatives and carbon dioxide without the use of polar cosolvents (Scheme 25 and Supporting Information File 1, Procedure 11). The Lewis acid $\mathrm{MgCl}_{2}$ is usually generated during the formation of the organozinc reagent by a magnesium insertion in the presence of $\mathrm{ZnCl}_{2}$ (compare section 1.2) [59,60].

Thus, 2-fluorophenylzinc bromide $\mathbf{1 6 3}$ and the pyrazolylzinc chloride 165 react at room temperature with the aromatic aldehydes to provide the secondary alcohols $\mathbf{1 6 4}$ and $\mathbf{1 6 6}$ in $87-91 \%$ yield. The alkyl zinc reagent 167 adds to $\alpha, \alpha, \alpha$-trifluoromethylacetophenone in $2 \mathrm{~h}$ and the corresponding alcohol 168 was isolated in $76 \%$ yield. Furthermore, the method was applied to the synthesis of the blockbuster drug ibuprofen (170). To achieve this, the secondary benzylic zinc reagent 169 was reacted with $\mathrm{CO}_{2}$ gas to provide the phenylacetic acid $\mathbf{1 7 0}$ in $89 \%$ yield.

\section{Conclusion}

We have summarized the most important procedures for the preparation of functionalized organzinc and organomagnesium reagents in this short review. Although, these reagents were introduced to synthetic organic chemistry at the turn of the $20^{\text {th }}$ century, they are now more than ever essential organometallic intermediates. The progress in the 5 last years in our laboratories shows that much is still unknown in this field, and that the important synthetic preparation methods developed recently will lead to a revolution in the field and considerably expand the use of these organometallics in synthesis.

\section{Experimental}

Experimental details for the most important reactions of this review are given in the Supporting Information File 1.

\section{Supporting Information}

\section{Supporting Information File 1}

Experimental section.

[http://www.beilstein-journals.org/bjoc/content/

supplementary/1860-5397-7-147-S1.pdf]<smiles>C=CCOc1ccc(C(O)c2cc(C)nn2-c2ccc(C(=O)OCC(C)(C)C(F)(F)F)cc2)cc1</smiles> 


\section{Acknowledgements}

This research was funded by the European Research Council under the European Union's Seventh Framework Programme (FP7/2007-2013) ERC grant agreement $\mathrm{n}^{\circ} 227763$. Furthermore, we thank the DFG (SFB 749) for financial support. We also thank Chemetall GmbH (Frankfurt), Umicore AG (Angleur, Belgium), Heraeus Holding GmbH (Hanau) and BASF SE (Ludwigshafen) for their generous donation of chemicals.

\section{References}

1. Knochel, P. Sci. Synth. 2004, 3, 5-90.

2. Knochel, P.; Millot, N.; Rodriguez, A.; Tucker, C. E. Org. React. 2001, 58, 417-731.

3. Knochel, P.; Almena Perea, J. J.; Jones, P. Tetrahedron 1998, 54, 8275-8319. doi:10.1016/S0040-4020(98)00318-4

4. Majid, T. N.; Knochel, P. Tetrahedron Lett. 1990, 31, 4413-4416. doi:10.1016/S0040-4039(00)97635-4

5. Zhu, L.; Wehmeyer, R. M.; Rieke, R. D. J. Org. Chem. 1991, 56, 1445-1453. doi:10.1021/jo00004a021

6. Krasovskiy, A.; Malakhov, V.; Gavryushin, A.; Knochel, P. Angew. Chem., Int. Ed. 2006, 45, 6040-6044. doi:10.1002/anie.200601450

7. Knochel, P.; Yeh, M. C. P.; Berk, S. C.; Talbert, J. J. Org. Chem. 1988, 53, 2390-2392. doi:10.1021/jo00245a057

8. Boudet, N.; Sase, S.; Sinha, P.; Liu, C.-Y.; Krasovskiy, A.; Knochel, P. J. Am. Chem. Soc. 2007, 129, 12358-12359. doi:10.1021/ja074060h

9. Piller, F. M.; Metzger, A.; Schade, M. A.; Haag, B. A.; Gavryushin, A.; Knochel, P. Chem.-Eur. J. 2009, 15, 7192-7202. doi:10.1002/chem.200900575

10. Negishi, E.; Valente, L. F.; Kobayashi, M. J. Am. Chem. Soc. 1980, 102, 3298-3299. doi:10.1021/ja00529a091

11. Negishi, E. Acc. Chem. Res. 1982, 15, 340-348. doi:10.1021/ar00083a001

12. Negishi, E.; Bagheri, V.; Chatterjee, S.; Luo, F.-T.; Miller, J. A.; Stoll, A. T. Tetrahedron Lett. 1983, 24, 5181-5184. doi:10.1016/S0040-4039(00)88391-4

13. Metzger, A.; Schade, M. A.; Knochel, P. Org. Lett. 2008, 10, 1107-1110. doi:10.1021/ol7030697

14. Schade, M. A.; Metzger, A.; Hug, S.; Knochel, P. Chem. Commun. 2008, 3046-3048. doi:10.1039/b803072c

15. Charles, M. D.; Schultz, P.; Buchwald, S. L. Org. Lett. 2005, 7, 3965-3968. doi:10.1021/ol0514754

16. Anderson, K. W.; Tundel, R. E.; Ikawa, T.; Altman, R. A.; Buchwald, S. L. Angew. Chem., Int. Ed. 2006, 45, 6523-6527. doi:10.1002/anie.200601612

17. Barder, T. E.; Buchwald, S. L. Org. Lett. 2004, 6, 2649-2652. doi:10.1021/ol0491686

18. Gavryushin, A.; Kofink, C.; Manolikakes, G.; Knochel, P. Org. Lett. 2005, 7, 4871-4874.

For other Ni-catalyzed cross-couplings of zinc reagents.

19. Gavryushin, A.; Kofink, C.; Manolikakes, G.; Knochel, P. Tetrahedron 2006, 62, 7521-7533. doi:10.1016/j.tet.2006.03.123

20. Rieke, R. D. Science 1989, 246, 1260-1264. doi:10.1126/science.246.4935.1260

21. Rieke, R. D.; Hanson, M. V. Tetrahedron 1997, 53, 1925-1956. doi:10.1016/S0040-4020(96)01097-6
22. Piller, F. M.; Appukkuttan, P.; Gavryushin, A.; Helm, M.; Knochel, P. Angew. Chem., Int. Ed. 2008, 47, 6802-6806. doi:10.1002/anie.200801968

23. Kondo, Y.; Shilai, M.; Uchiyama, M.; Sakamoto, T. J. Am. Chem. Soc. 1999, 121, 3539-3540. doi:10.1021/ja984263t

24. Hlavinka, M. L.; Hagadorn, J. R. Tetrahedron Lett. 2006, 47, 5049-5053. doi:10.1016/j.tetlet.2006.05.093

25. Krasovskiy, A.; Krasovskaya, V.; Knochel, P. Angew. Chem., Int. Ed. 2006, 45, 2958-2961. doi:10.1002/anie.200504024

26. Lin, W.; Baron, O.; Knochel, P. Org. Lett. 2006, 8, 5673-5676. doi:10.1021/ol0625536

27. Chemetall GmbH Frankfurt; contact: christoph.krinninger@chemetall.com

28. Wunderlich, S. H.; Knochel, P. Angew. Chem., Int. Ed. 2007, 46, 7685-7688. doi:10.1002/anie.200701984

29. Mulvey, R. E.; Mongin, F.; Uchiyama, M.; Kondo, Y. Angew. Chem., Int. Ed. 2007, 46, 3802-3824. doi:10.1002/anie.200604369

30. Wunderlich, S.; Knochel, P. Org. Lett. 2008, 10, 4705-4707. doi:10.1021/ol802118e

31. Knochel, P.; Dohle, W.; Gommermann, N.; Kneisel, F. F.; Kopp, F.; Korn, T.; Sapountzis, I.; Vu, V. A. Angew. Chem., Int. Ed. 2003, 42, 4302-4320. doi:10.1002/anie.200300579

32. Ila, H.; Baron, O.; Wagner, A. J.; Knochel, P. Chem. Commun. 2006, 583-593. doi:10.1039/b510866g

33. Ila, H.; Baron, O.; Wagner, A. J.; Knochel, P. Chem. Lett. 2006, 35, 2-7. doi:10.1246/cl.2006.2

34. Jensen, A. E.; Dohle, W.; Sapountzis, I.; Lindsay, D. M.; Vu, V. A.; Knochel, P. Synthesis 2002, 565-569. doi:10.1055/s-2002-20955

35. Krasovskiy, A.; Knochel, P. Angew. Chem., Int. Ed. 2004, 43, 3333-3336. doi:10.1002/anie.200454084

36. Boudet, N.; Lachs, J. R.; Knochel, P. Org. Lett. 2007, 9, 5525-5528. doi:10.1021/ol702494k

37. Krasovskiy, A.; Straub, B. F.; Knochel, P. Angew. Chem., Int. Ed. 2006 45, 159-162. doi:10.1002/anie.200502220

38. Wang, X.-j.; Xu, Y.; Zhang, L.; Krishnamurthy, D.; Senanayake, C. H. Org. Lett. 2006, 8, 3141-3144. doi:10.1021/ol061156s

39. Knochel, P.; Krasovskiy, A.; Sapountzis, I. Polyfunctional Magnesium Organometallics for Organic Synthesis. In Handbook of Functionalized Organometallic; Knochel, P., Ed.; Wiley-VCH: Weinheim, Germany, 2005; Vol. 1, pp 109-172. doi:10.1002/9783527619467.ch4

40. Ren, H.; Krasovskiy, A.; Knochel, P. Chem. Commun. 2005, 543-545. doi:10.1039/b415588b

41. Liu, C.-Y.; Ren, H.; Knochel, P. Org. Lett. 2006, 8, 617-619. doi:10.1021/ol052792d

42. Liu, C.-Y.; Knochel, P. J. Org. Chem. 2007, 72, 7106-7115. doi:10.1021/jo070774z

43. del Amo, V.; Dubbaka, S. R.; Krasovskiy, A.; Knochel, P. Angew. Chem., Int. Ed. 2006, 45, 7838-7842. doi:10.1002/anie.200603089

44. Boudet, N.; Dubbaka, S. R.; Knochel, P. Org. Lett. 2008, 10, 1715-1718. doi:10.1021/ol800353s

45. Yamada, S.; Gavryushin, A.; Knochel, P. Angew. Chem., Int. Ed. 2010, 49, 2215-2218.

For selective fluorinations of Grignard-reagents.

46. Mosrin, M.; Knochel, P. Org. Lett. 2008, 10, 2497-2500. doi:10.1021/ol800790g

47. Stoll, A. H.; Knochel, P. Org. Lett. 2008, 10, 113-116. doi:10.1021/ol7025872 
48. Koradin, C.; Dohle, W.; Rodriguez, A. L.; Schmid, B.; Knochel, P. Tetrahedron 2003, 59, 1571-1587.

doi:10.1016/S0040-4020(03)00073-5

49. Clososki, G. C.; Rohbogner, C. J.; Knochel, P. Angew. Chem., Int. Ed. 2007, 46, 7681-7684. doi:10.1002/anie.200701487

50. de Meijere, A.; Diederich, F. Metal-Catalyzed Cross-Coupling Reactions, 2nd ed.; Wiley-VCH: Weinheim, Germany, 2004. doi:10.1002/9783527619535

51. Tsuji, J. Transition Metal Reagents and Catalysts: Innovations in Organic Synthesis; John Wiley \& Sons: Chicester, U.K., 1995.

52. Beller, M.; Bolm, C., Eds. Transition Metals for Organic Synthesis; Wiley-VCH: Weinheim, Germany, 1998.

53. Manolikakes, G.; Schade, M. A.; Muñoz Hernandez, C.; Mayr, H.; Knochel, P. Org. Lett. 2008, 10, 2765-2768. doi:10.1021/ol8009013

54. Manolikakes, G.; Muñoz Hernandez, C.; Schade, M. A.; Metzger, A.; Knochel, P. J. Org. Chem. 2008, 73, 8422-8436. doi:10.1021/j08015852

55. Corriu, R. J. P.; Masse, J. P. J. Chem. Soc., Chem. Commun. 1972, 144.

56. Tamao, K.; Sumitani, K.; Kumada, M. J. Am. Chem. Soc. 1972, 94, 4374-4376. doi:10.1021/ja00767a075

57. Manolikakes, G.; Knochel, P. Angew. Chem., Int. Ed. 2009, 48 205-209. doi:10.1002/anie.200803730

58. Kienle, M.; Knochel, P. Org. Lett. 2010, 12, 2702-2705. For an iPrl accelerated Negishi coupling.

59. Metzger, A.; Bernhardt, S.; Manolikakes, G.; Knochel, P. Angew. Chem., Int. Ed. 2010, 49, 4665-4668. doi:10.1002/anie.201000634

60. Bernhardt, S.; Metzger, A.; Knochel, P. Synthesis 2010, 3802-3810. doi:10.1055/s-0030-1258314

\section{License and Terms}

This is an Open Access article under the terms of the Creative Commons Attribution License (http://creativecommons.org/licenses/by/2.0), which permits unrestricted use, distribution, and reproduction in any medium, provided the original work is properly cited.

The license is subject to the Beilstein Journal of Organic Chemistry terms and conditions:

(http://www.beilstein-journals.org/bjoc)

The definitive version of this article is the electronic one which can be found at: doi:10.3762/bjoc.7.147 